\title{
Cell-to-Cell Communication During Plant-Pathogen Interaction
}

\author{
Naheed Tabassum and Ikram Blilou ${ }^{\dagger}$ \\ King Abdullah University of Science and Technology (KAUST), Thuwal, Saudi Arabia
}

Accepted 11 October 2021.

\begin{abstract}
Being sessile, plants are continuously challenged by changes in their surrounding environment and must survive and defend themselves against a multitude of pathogens. Plants have evolved a mode for pathogen recognition that activates signaling cascades such as reactive oxygen species, mitogenactivated protein kinase, and $\mathrm{Ca}^{2+}$ pathways, in coordination with hormone signaling, to execute the defense response at the local and systemic levels. Phytopathogens have evolved to manipulate cellular and hormonal signaling and exploit hosts' cell-to-cell connections in many ways at multiple levels. Overall, triumph over pathogens depends on how efficiently the pathogens are recognized and how rapidly the plant response is initiated through efficient intercellular communication via apoplastic and symplastic routes. Here, we review how intercellular communication in plants is mediated, manipulated, and maneuvered during plant-pathogen interaction.
\end{abstract}

Keywords: bacterial pathogenesis, cell-to-cell communication, fungus-plant interactions, nematode-plant interactions, oomyceteplant interactions, plant defense, plant responses to pathogens, plasmodesmata, phytohormone, virus movement, virus-plant interactions

Plants are constantly challenged by their continuously changing environment and are hijacked by a myriad of soil and airborne pathogens. To thrive in these unstable conditions, plants have evolved an excellent cell-to-cell communication system. In both plants and animals, cell-to-cell communication is a process that is highly regulated. Cells must receive the proper information required for specifying cell fate, forming tissues and organs, and building a robust defense mechanism against pathogens. Here, we highlight how intercellular communication is mediated in plants and how pathogens take advantage of this system to dupe plants by exploiting their two main types of communication: apoplastic and symplastic.

\section{Apoplastic communication.}

The apoplast is the space outside the plasma membrane (PM), within which water and solutes can be freely transported across tissues or organs. Therefore, the apoplast is an

${ }^{\dagger}$ Corresponding author: I. Blilou; ikram.blilou@kaust.edu.sa

The author(s) declare no conflict of interest. the Creative Commons CCO "No Rights Reserved" license by waiving all of his or her rights to the work worldwide under copyright law, including all related and neighboring rights, to the extent allowed by law, 2022. ideal site for propagating and spreading pathogens from cell to cell. However, plants tightly regulate the essential apoplastic content targeted by the pathogens such as water, sugar, iron, reactive oxygen species (ROS), and $\mathrm{pH}$ in response to an attack (Aung et al. 2018; Qi et al. 2017). Plants also create apoplastic barriers by remodeling their cell membranes and walls in response to pathogens to restrict an infection.

A recent study revealed that the apoplast mediates the transport of such hormones as salicylic acid (SA) during pathogen infection in leaves. The accumulation of SA in an apoplast is driven by a $\mathrm{pH}$ gradient and is regulated by the cuticle (Lim et al. 2020). One of the critical apoplastic communication methods is long-distance ROS signaling during the respiratory or oxidative burst in response to abiotic or biotic stimuli. Nicotinamide adenine dinucleotide phosphate oxidase (NADPH oxidase), a PM-localized enzyme, produces superoxide radicals in the apoplast, which are converted to $\mathrm{H}_{2} \mathrm{O}_{2}$ either spontaneously or by superoxide dismutase present in the apoplast. However, apoplastic communication can be obstructed by apoplastic salt precipitates (Ranathunge et al. 2005).

\section{Symplastic communication.}

To overcome a rigid cell wall, plants have evolved symplastic communication through pores connecting cytoplasmic streams of two adjacent cells. Traversing the cell wall, plasmodesmata (PDs) are intercellular pores or bridges that allow symplastic communication between adjacent cells. PDs facilitate intercellular trafficking, passage, and signaling between cells (Lucas and Lee 2004). Structurally, they are lined by the PM and occupied by an intricate and complex structure of the endoplasmic reticulum (ER) fueled with PD and cytoskeletal proteins such as actin and myosin. The cylindrical segment of ER connecting two cells is known as a desmotubule. The lipid and protein composition of the PD PM is different from the rest of the cellular PM, which functions as a discrete PM microdomain (FernandezCalvino et al. 2011; Grison et al. 2015). Transmission electron microscopy shows a typical (simple) PD with a diameter of $50 \mathrm{nM}$ (Bell and Oparka 2011).

In addition to nutrients, hormones, signaling molecules, and RNA, the PDs actively facilitate the trafficking of numerous noncell-autonomous proteins in different plant organs (Gundu et al. 2020). In the shoot apical meristem, the homeodomain transcription factor WUSCHEL (WUS) is expressed in the organizing center, and its protein moves to the stem cells located at the outermost cell layer through the PD to keep them in an undifferentiated state and, thus, function noncell-autonomously (Daum et al. 2014). In roots, the cell-fate determinant SHORTROOT (SHR) moves from the stele to the outer layer, which is the endodermis and quiescent center, to control asymmetric cell division that gives rise to the cortex and endodermis to promote the 
endodermal cell fate and maintain the quiescent center function (Helariutta et al. 2000; Nakajima et al. 2001). Both WUS and SHR have been demonstrated to traffic through the PD.

The passage of proteins through the PD is highly selective and is mediated by callose ( $\beta-1,3$ glucan polymer) deposition at the PD orifice, reducing the size exclusion limit. The PD-located proteins, including PD-localized proteins (PDLPs), PD-associated $\beta-1,3$ glucanase, PD-associated callose binding protein, callose synthase (CalS)/glucan synthase-like (GSL), and remorin-like proteins, regulate PD-callose homeostasis. A decreased PD permeability correlates with ROS accumulation (Cui and Lee 2016). The redox states of the cellular organelles such as mitochondria and chloroplast regulate PD permeability (BenitezAlfonso et al. 2009; Stonebloom et al. 2012).

\section{PLANT-PATHOGEN INTERACTION DURING CELL-TO-CELL COMMUNICATION}

\section{Preformed defense.}

As the first line of defense, plants use physical barriers to restrict the spread of pathogens from one cell to another. These barriers include the cuticle in leaves (cutin and waxes) and the cell wall (cellulose, hemicellulose, pectin, and proteins) (Somerville et al. 2004; Yeats and Rose 2013). In roots, cellwall modifications include forming Casparian strips in the endodermis and depositing lignin, suberin (phenolic compound), lamellae, and secondary walls (Geldner 2013; Thomas et al. 2007). These act as apoplastic barriers for the entry and colonization of pathogens because mutants that are defective in cellulose or lignin synthesis are more susceptible to pathogens (Miedes et al. 2014).

The second level of defense includes a range of constitutive secondary metabolites such as antimicrobial proteins (defensin or defensin-like proteins) and chemicals (saponin and glucosinolates), generally called phytoanticipins (Osbourn 1996; Tierens et al. 2001). When a potential pathogen enters the host's apoplast by releasing cell-wall-degrading enzymes (Bellafiore et al. 2008; Kämper et al. 2006), the "danger" cues (ROS and damage-associated molecular components) can be sensed by neighboring cells via intercellular signaling, priming the neighboring cells through the de novo synthesis of phytoalexins. Phytoalexins (e.g., camalexin) can interfere with the pathogen's metabolism or maturation, leading to their inhibition. Plants also secrete proteases in the apoplast to suppress bacterial growth at a low $\mathrm{pH}$ (Wang et al. 2020), followed by intricate intra- and intercellular signaling, collectively known as apoplast immunity, an interface between preformed and induced defense.

\section{Induced defense.}

When potential phytopathogens breach the barriers mentioned above and reach the apoplasts, the plants activate the third level of inducible defense. This type of plant-pathogen interaction operates as a zig-zag model in three successive steps: pathogenassociated molecular pattern (PAMP)-triggered immunity (PTI), effector-triggered susceptibility (ETS), and effector-triggered immunity (ETI) (Jones and Dangl 2006) (Fig. 1).

\section{PTI.}

Plants recognize PAMPs by specific membrane-localized pattern recognition receptors. The recognition of PAMPs (e.g., flg22, a conserved flagellar 22 amino acid long peptide) via pattern recognition receptors (FLS2 and BAK1) induces a complex network of signaling pathways such as mitogen-activated protein kinase (MAPK) signaling, $\mathrm{Ca}^{2+}$ signaling, ion flux changes, defense hormones, and transcriptional reprogramming, collectively called PTI (Fig. 1B) (Jones and Dangl 2006; Zhou and Zhang 2020). Some defense responses are executed through the apoplast, including the accumulation of apoplastic ROS, a restricted efflux of nutrients from the cytosol to the apoplast, and the production and secretion of antimicrobial compounds such as camalexin (Ahuja et al. 2012; O’Brien et al. 2012).

Moreover, MPK3- and MPK6-mediated phosphorylation of transcription factor WRKY33 regulates the production of camalexin (Mao et al. 2011). One of the hallmarks of PTI is the increased regulation of symplastic trafficking through callose deposition in the PD orifice to limit cell-to-cell communication (Faulkner et al. 2013; Stahl and Faulkner 2016; B. Xu et al. 2017). A lower level of callose deposition is often correlated with higher infection and vice versa (Voigt and Somerville 2009). The PD-localized calcium-binding protein calmodulinlike protein 41 plays a crucial role in flg22-induced PD closure to regulate plant immunity (B. Xu et al. 2017).

Chitin (a fungal PAMP), perceived by the PD PM-located lysin motif domain-containing glycosylphosphatidylinositolanchored protein 2 (LYM2), triggers PD closure (Faulkner et al. 2013). The PD closure does not require the receptor chitin elicitor receptor kinase 1 located in the cellular PM. Cheval and Faulkner (2018) demonstrated that LYM2 induces phosphorylation and activation of NADPH oxidase respiratory burst oxidase homolog protein $\mathrm{D}$ and requires the calcium-dependent protein kinases (CPKs) CPK6 and CPL11 to mediate chitin-triggered PD closure through callose deposition.

These studies illustrated the specificity and significance of PD in the PTI response that integrates calcium and ROS signaling. However, the degree and mode of action or inhibition cannot be generalized. For instance, the roots have a zone type-specific response. The flg22-induced PTI response is spatially restricted in the root cap and the elongation zone, whereas elf18 induces little response overall. Moreover, chitin elicits a directional response in the differentiated zone (Kunze et al. 2004; Zhou et al. 2020). Laser-induced cell ablation in the epidermis strongly induces the PAMP response in the stele of the root but not in the neighboring epidermal cells (Zhou et al. 2020). This outcome could be due to less counter-mechanical stimulation or pressure from underlying cells or the perception of the collapse of PD integrity, which are of different degrees and quality in cortical and epidermal cells.

The application of ROS decreases the permeability of the PD, presumably via regulating callose synthesis and deposition (Cui and Lee 2016; Thomas et al. 2008). However, the mechanism and key players behind the ROS-mediated PD regulation during PTI in unknown. It is speculated that PDLP1 and PDLP5, which are associated with the immune response in Arabidopsis (Caillaud et al. 2014; Wang et al. 2013), could function with the domain of an unknown function protein (DUF26), which is proposed to be involved in ROS perception and signaling (Bourdais et al. 2015) and, thus, could mediate PAMPtriggered ROS signals (Cheval and Faulkner 2018).

ETS.

To overcome PTI, some pathogens deliver specialized virulence factors or effectors to the plant apoplast (apoplastic effectors) or directly inside cells (cytosolic effectors) which cause disease in susceptible plants, commonly called ETS (Fig. 1C). Pathogens' diverse effectors may interfere with defense by various mechanisms in a spatially or temporally dependent manner, and the mode of invasion and action can vary from effector to effector (Toruño et al. 2016). Some effectors open up natural openings such as stomata for apoplastic colonization. Others move from cell to cell, exploiting the intercellular connection, and may target different cellular processes. For instance, effector protein RxLR3 from Phytophthora brassicae interacts with the PD-localized callose synthases CalS1, CalS2, and CalS3 and inhibits callose deposition to promote symplastic cell-to-cell 
A

Resting stage

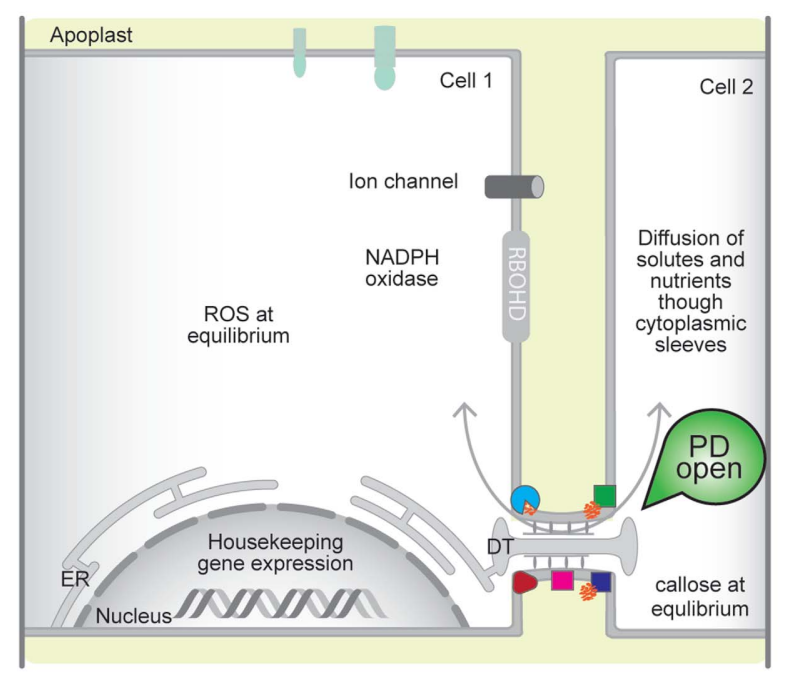

C Effector-triggered susceptibility (ETS)

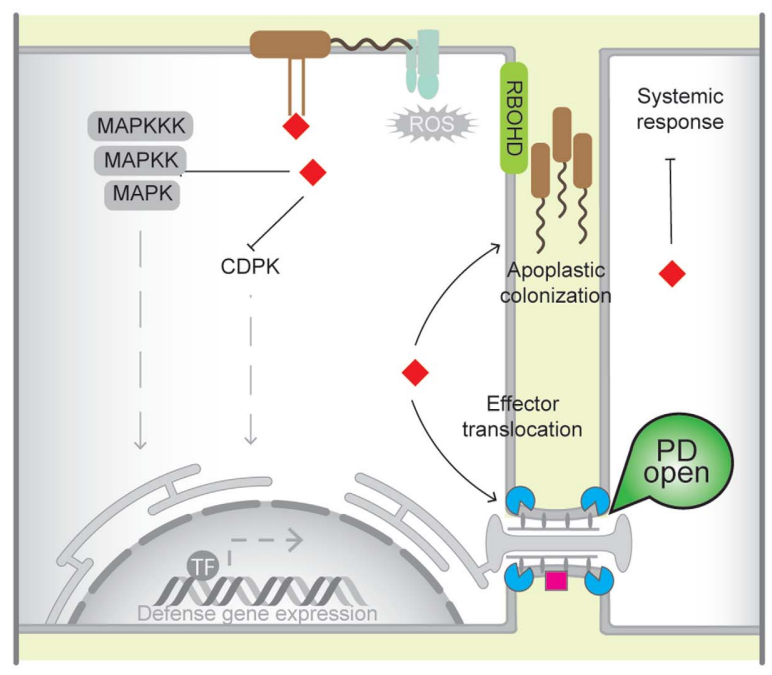

B

PAMP-triggered immunity (PTI)
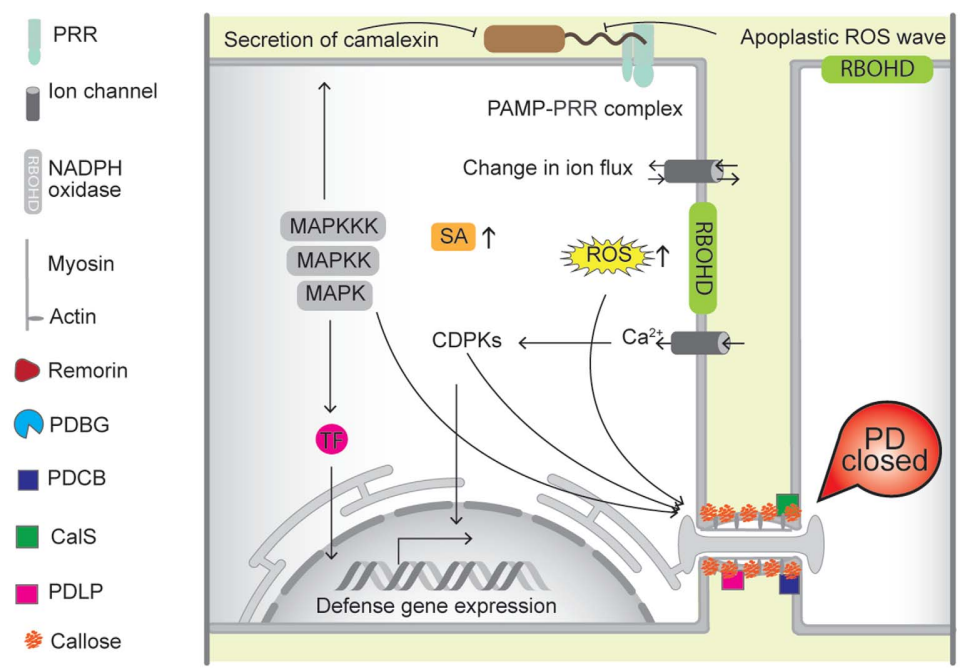

D

Effector-triggered immunity (ETI)
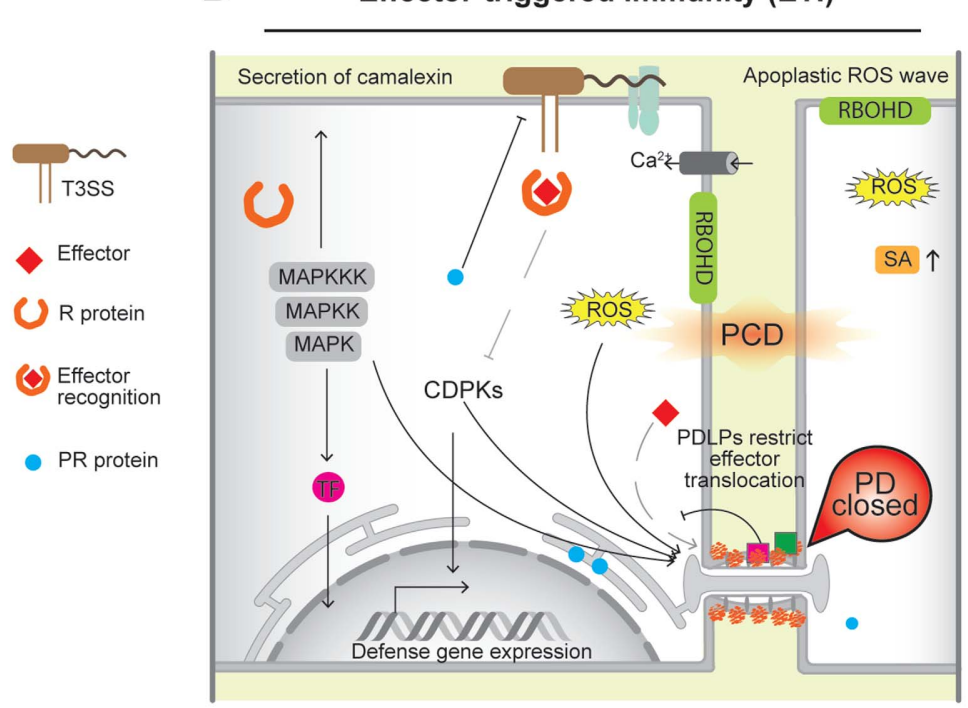

E Systemic acquired resistance (SAR)

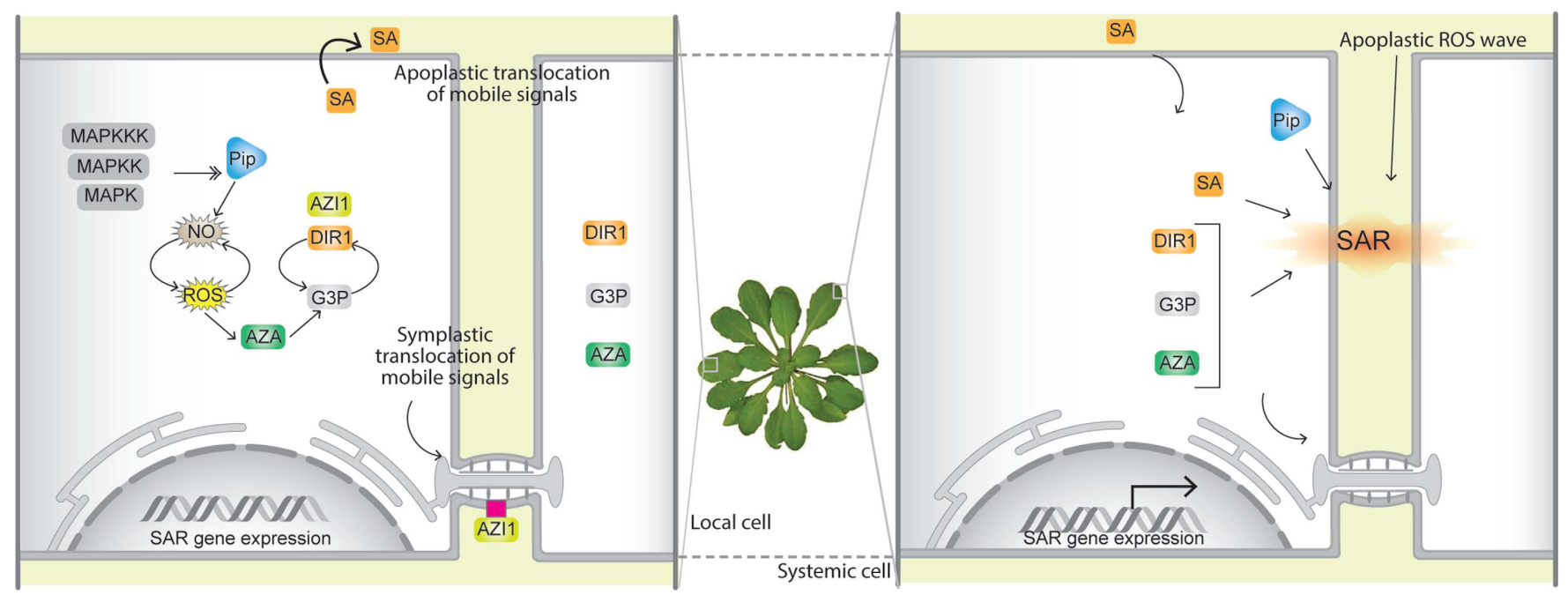


trafficking in the leaf (Tomczynska et al. 2020). In addition, PWL2 and BAS1 effectors secreted by the infection hyphae of the rice blast fungus first accumulate at the biotrophic interfacial complex, then symplastically move from one cell to another. The effectors may move ahead of the infection hyphae, depending on the size of the effector and the cell type (Khang et al. 2010).

In contrast, another effector, BAS4, uniformly expressed in the infection hyphae, does not translocate through the cytoplasm. The corn smut effector Cmu1, which disrupts the SA signaling pathway, moves symplastically (Djamei et al. 2011). Bacteria such as Pseudomonas syringae strain DC3000 deliver dozens of effectors using the type III secretion system, affecting multiple components and manipulating cellular processes and intercellular communication (Aung et al. 2020; Lewis et al. 2009). A recent study demonstrated that the movement of effectors such as other molecules across the PD largely depends on their molecular weight (Li et al. 2021). The cell-to-cell movement of effectors possibly primes host cells for further pathogen colonization (Toruño et al. 2016). The exact mechanism of the movement of effectors through the PD and whether this movement is regulated remain to be deciphered.

\section{ETI.}

Resistant plants have evolved to recognize effectors via intracellular nucleotide binding site (NBS) and the leucine-rich (LRR) repeat domain or resistance proteins and counterattack by inducing ETI (Fig. 1D). The amplitude and acceleration of ETI are faster than PTI, usually causing localized cell death, called hypersensitive response (HR), at the infection site.

However, recent data indicate positive feedback regulation between PTI and ETI. The ETI boosts PTI responses, and PTI strengthens ETI-induced HR during $P$. syringae strain DC3000 infection (Ngou et al. 2020). In addition, HR is believed to work in concert with callose deposition (Rinne and van der Schoot 2003). One of the hallmarks of ETI is the synthesis of pathogenesis-related proteins, which are localized to PD in maize and restrict PD permeability (Murillo et al. 1997).

Recently, more evidence associates ETI with the PD function. For instance, upon recognizing an effector from $P$. syringae, HopW1-1 induces a resistance response such as the accumulation of the signal molecule SA, inducing the expression of several defense-related genes (Lee et al. 2008). One of the induced genes is HopW1-1, a member of the PDLP gene family, indicating the role of ETI in PD trafficking (Lee and Lu 2011; Thomas et al. 2008). In addition, PDLP5 and PDLP7 negatively regulate the symplastic movement of the $P$. syringae strain DC3000 effector HopAF1.

Another study demonstrated that two effectors, Avr2 and Six5, from the fungus Fusarium oxysporum are required for ETI in the tomato. Furthermore, Avr2 and Six 5 interact at the PD, and Avr2 moves from cell to cell in the presence of Six5, causing disease in susceptible plants. However, HR is induced when the I-2 protein recognizes Avr2 in the xylem-adjacent cell of the resistant plant (Cao et al. 2018). The electrophysical study of
HR induced by the effector avrRpt 2 revealed the occurrence of a rapid, irreversible depolarization of the membrane that might propagate through the PD (Pike et al. 2005).

\section{Systemic acquired resistance.}

Activation of the abovementioned local defense signaling might lead to the induction of cell-to-cell communication and execution defense responses at the systemic level, known as systemic acquired resistance (SAR) (Fig. 1E). In addition, SAR can be described as the fourth level of defense response because it ensures enhanced resistance against the subsequent pathogenic challenge. Furthermore, SAR activation depends on two signaling pathways to generate signaling molecules, such as azelaic acid and glycerol-3-phosphate: (i) SA and the signaling protein NONEXPRESSOR OF PATHOGENESIS-RELATED GENES 1 (NPR1) and (ii) ROS and nitric oxide (Singh et al. 2017). The SAR signaling molecule is transported from the site of infection to distantly located uninfected tissues.

Moreover, SA moves apoplastically, whereas azelaic acid and glycerol-3-phosphate both use the symplastic route to track the vasculature and eventually distribute to systemic tissues (Lim et al. 2016; Yu et al. 2013). Defective in induced resistance 1 (DIR1) is a lipid transfer protein involved in SAR, moving symplastically (Carella et al. 2015). When these signals arrive at systemic tissues, they initiate the de novo synthesis of defense-related molecules, which could lead to activating SAR (Lim et al. 2016; Singh et al. 2017; Yu et al. 2013).

The PDLPs interact and modulate the stability of SAR components. For instance, azelaic acid induced 1 (AZI1), a DIR1interacting protein required for SAR, interacts with PDLP1 and PDLP5. In addition, PDLP1 and PDLP5 are required for AZI1 stability, and the loss of either PDLP1 or PDLP5 leads to the delocalization of AZI1 to chloroplasts (Carella et al. 2015; Lim et al. 2016). The systemic movement of DIR1 is also abolished in plants overexpressing PDLP1 and PDLP5, indicating that feedback regulation through $\mathrm{PD}$ is crucial for long-distance SAR signaling (Carella et al. 2015). It is suggested that PDLPs involved in SAR retain their localization to PD but PDLPs can relocalize to different cell compartments during defense (Caillaud et al. 2014).

Another mobile element contributing to SAR is pipecolic acid. Pipecolic acid functions upstream of nitric oxide or ROS, azelaic acid, and glycerol-3-phosphate pathways and is synthesized by aberrant growth and death 2 (AGD2)-like defense response protein 1. Wang et al. (2018) demonstrated that the accumulation of pipecolic acid and expression of AGD2-like defense response protein 1 are induced by the activation of the MAPK enzymes MPK3 and MPK6 and the phosphorylation of downstream WRKY33, suggesting the critical role of MAPK signaling in SAR establishment.

\section{CELL-TO-CELL COMMUNICATION, HORMONES, AND DEFENSE}

Plant hormones such as auxin, gibberellins (GA), abscisic acid (ABA), cytokinins (CK), SA, ethylene (ET), jasmonates

Fig. 1. Plant defense is executed through intercellular communication. A, Resting stage. Callose hemostasis is regulated by plasmodesmata (PD)-located proteins: PD-localized proteins (PDLPs), PD-associated $\beta-1,3$ glucanase (PDGB), PD-associated callose binding protein (PDCB), and callose synthase (CalS)/glucan synthase-like (GSL). B, Pathogen-associated molecular pattern (PAMP)-triggered immunity (PTI). Detection of PAMP using a pattern recognition receptor (PRR) activates early immune responses such as the production of reactive oxygen species (ROS), activation of mitogen-activated protein kinase (MAPK), $\mathrm{Ca}^{2+}$ signaling, defense gene expression, and PD closure through callose deposition, secretion of secondary metabolites, and the establishment of an ROS wave in the apoplast. C, Effector-triggered susceptibility (ETS). Effectors delivered by type III secretion system may negatively regulate MAPK and $\mathrm{Ca}^{2+}$ signaling, inhibiting defense gene expression. Effectors may assist in apoplastic colonization to suppress the immune response or may translocate through the PD to inhibit the systemic response. D, Effector-triggered immunity (ETI). Effector recognition by resistance protein triggers early and late immune responses such as the synthesis of pathogenesis-related (PR) proteins, and the restricted translocation of effectors by PDLPs helps in the hypersensitive response. E, Systemic acquired resistance (SAR). Execution of defense responses in distantly located cells mediates mobile signaling molecules translocated through the PD or apoplast. The master regulator of SAR, pipecolic acid, is regulated by MAPK signaling in the local cell. 
(JA), brassinosteroids, and strigolactones, play essential roles in integrating developmental and environmental cues. Although these are transported through the PD, many (e.g., SA, JA, GA, and auxin) regulate PD permeability under stress (Farmer et al. 2014; Han et al. 2014; Wang et al. 2013). In addition to the intercellular movement, phytohormones are detected in the phloem sap (e.g., SA), suggesting that plants may strategically use these micromolecules as signaling molecules at the local or systemic level (Lee and Frank 2018). Pathogens have evolved to manipulate the host defense system by producing hormones or their functional mimics or exploiting their antagonistic relationships and complex crosstalk. Selected hormones involved in defense and PD regulation are discussed below.

\section{SA.}

The accumulation of SA is required for both basal and induced immune responses ( $\mathrm{Fu}$ and Dong 2013). A recent study found that intercellular communication during ETI is essential for cell survival (Zavaliev et al. 2020). Moreover, HR in distal tissue from the infection site promotes SA-inducing NPR1 condensation, in which NPR1 associates with an E3 ubiquitin ligase complex, and stress-related proteins are targeted to the proteasome. This phenomenon was not observed in the nprl mutant, indicating that NPR1 is required for cell survival and inhibits ETI in secondary infections (Mittag and Strader 2020).

Although manipulating hormone signaling may confer resistance in plants, their constitutive induction also leads to pleiotropic effects on plant growth. This can, however, be avoided by the spatiotemporal regulation of gene expression. For example, a rice-blast-resistant plant was produced using controlled transcription and translation of NPR1 without affecting the growth and yield (G. Xu et al. 2017).

A molecular link between the regulation of immunity, hormonal signaling, and PD permeability has also been demonstrated. A PD-resident protein required for PD closure and basal immunity, PDLP5 is expressed at a low level in the absence of a pathogen attack. However, the expression is increased upon a pathogenic attack and the exogenous application of SA (Lee et al. 2011). Overexpression of PDLP5 reduced the PD permeability but both overexpression and loss of function result in a compromised SAR (Lim et al. 2016).

Another study found that the exogenous application of SA induces callose deposition and regulates PD closure (Wang et al. 2013). Callose synthase genes CALS1 and CALS8 are upregulated by an increased level of SA and ROS, respectively, both playing a role in PD closure (Cui and Lee 2016). A recent study demonstrated that SA triggers PD closure by reorganizing the PM lipid raft nanodomain (Huang et al. 2019). In addition, SA modulates the lipid raft-regulatory protein remorin (which is crucial for PM nanodomain assembly) and triggers the compartmentalization of the lipid raft nanodomain. This action results in the closure of the PD to restrict the spread of the virus (Huang et al. 2019). A remorin from Nicotiana (REM4) was recently found to interact with the effector HopZ1a, inducing ETI (Albers et al. 2019).

\section{JA.}

Plants produce JA, which can be apoplastically or symplastically transported from cell to cell as a defense hormone against various pathogens ( $\mathrm{Li}$ et al. 2017; Mielke et al. 2011). Plants overexpressing PDLP5 have high JA in exudates and a reduced size exclusion limit, suggesting lower symplastic access of JA to the phloem (Lim et al. 2016). In addition, RipE1, an effector from Ralstonia solanacearum, is delivered in the host through the Hrp type III secretion system. Moreover, RipE1 is a protease that degrades the JAZ repressor and induces the expression of JA-responsive genes. The induction of JA signaling suppresses SA signaling and helps bacteria establish successful infection and bacterial wilt through ETS (Nakano and Mukaihara 2019).

\section{Auxin.}

Auxin regulates growth and development, which may be closely linked to defense signaling (Kazan and Manners 2009). Despite being a small and expectedly freely diffusible molecule, its tissue gradient is highly regulated across the PD through de novo callose deposition (Han et al. 2014). The auxin-PD-callose feedback loop regulates the symplastic transport of auxin in the hypocotyl and leaf for the phototropic response in the root for lateral root emergence (Gao et al. 2020; Sager et al. 2020). The reduction of enzyme activity such as GLS8/CalS10 (an enzyme involved in callose synthesis) indicates reduced apoplastic auxin transport and increased PD permeability (Han et al. 2014). The synthesis of callose suppresses cell death induced by a low calcium level. In addition, GSL10/CalS9 is required to alleviate defense response and cell-wall damage under low calcium conditions (Shikanai et al. 2020). Furthermore, GSL8 interacts with PDLP5 and GSL10 (Saatian et al. 2018). Symplastic transport of other signaling agents, including macromolecules, might be regulated by auxin or regulated with cross-talk in different pathways (Band 2021; Han et al. 2014). Overall, these data point to an intricate signaling network of defense (calcium signaling and callose synthesis) and hormone (auxin) transportation through the PD.

\section{ABA.}

ABA is known to play a role in stomatal immunity (closure of the stomata after PAMP perception to restrict pathogen entry) against a broad spectrum of pathogens. However, ABA perception through the PYR1 receptor modulates the cross-talk between SA and ET signaling, redirecting the defense outcome (García-Andrade et al. 2020). Overexpression of ERF8, an $\mathrm{ABA}$-inducible transcriptional repressor, negatively regulates ABA-mediated signaling and induces PCD in plants. In addition to accumulating apoplastic ROS, ABA signaling plays a role in bud dormancy and biotic stress such as the cell-tocell spread of viruses and fungi by regulating the PD permeability through callose deposition, the number of $\mathrm{PD}$, and the formation of a secondary PD (Alazem and Lin 2017; Kitagawa et al. 2019). The antiviral role of ABA is also achieved by the induced expression of RNA-silencing pathway genes (Alazem and Lin 2017).

CK.

A recent study found that $\mathrm{CK}$ induces systematic immunity in the tomato against fungi, dependent on SA and ET (Gupta et al. 2020). The exogenous application of CK also enhances the formation of a secondary PD in Sinapis alba (Ormenese et al. 2006). The PD callose regulates the long-distance movement of CK (Bishopp et al. 2011).

\section{ET and GA.}

The role of ET and GA in immunity has been extensively studied (De Bruyne et al. 2014; Guan et al. 2015). However, its dual function in regulating PD permeability and immunity is not yet reported. Moreover, $P$. syringae effector HopAF1, whose translocation is regulated by PDLPs during ETI, blocks ET induction to suppress immunity (Washington et al. 2016). In addition, GA regulates PD permeability, presumably through PD-associated $\beta-1,3$ glucanase, and the expression of $P D B G$ mRNAs requires GA during development and stress (Rinne et al. 2001; Wu and Bradford 2003). Due to this evidence, it would be interesting to study how ET and GA (individually or through hormonal cross-talk) regulate cell-to-cell communication during plant-pathogen interaction (Table 1). 


\section{HOW PATHOGENS EXPLOIT HOSTS' CELL-TO- CELL CONNECTION}

Pathogens enter a host cell through a natural opening (e.g., stomata), wound, or tissue damage. The mode for infection varies from pathogen to pathogen (Fig. 2). For instance, nematodes and bacteria commonly use the apoplastic passage for colonization, whereas viruses and fungi exploit the symplastic passage for cell-to-cell spread (Kankanala et al. 2007).

\section{Nematodes.}

Sedentary endoparasite cyst nematodes and root-knot nematodes locate the host and penetrate through the roots in second-stage juveniles. The root-knot nematodes migrate through intercellular spaces in the cortex, reaching the xylem parenchyma and inducing the formation of the feeding structure of giant cells (Jones 1981; Wyss and Grundler 1992). Cyst nematodes with a more robust stylet migrate through penetrating the cortex and endodermis, reaching the vascular cylinder and establishing the syncytia (von Mende 1997). Giant cells are symplastically isolated and obtain nutrition through a transport-mediated process, whereas the syncytia are connected to the phloem by the PD (Hoth et al. 2008). Nematodes initiate the de novo formation of unloading the phloem and secondary PD biogenesis between the sieve elements that connect to syncytia to ensure macromolecular trafficking (Hofmann and Grundler 2006; Hoth et al. 2008). They also release effector repertoires that may suppress the host defense response, alter hormone signaling, and modify or degrade the cell wall to ensure a constant nutrient supply and further establish a systemic infection (Hewezi and Baum 2017).

\section{Viruses.}

Plant viruses are biotrophic obligate pathogens known to spread by hijacking trafficking through the PD. They encode the movement protein (MP) to transport their genomes across cells. Different MPs use different mechanisms for virus transport. Some viruses, such as the tobacco mosaic virus, require a single MP and not the coat protein (CP) for intercellular movement. Nontubule-forming viruses associate with PD via MP to facilitate movement by increasing the size exclusion limit of the PD (Schoelz et al. 2011). In contrast, the cucumber mosaic virus and Alfalfa mosaic virus require a single MP and CP for cellto-cell movement (Kaplan et al. 1998). Some viruses such as the papaya mosaic virus and potato virus $\mathrm{X}$ have specialized open reading frames, known as triple gene blocks, which are required for movement through the PD and phloem (Morozov and Solovyev 2003).
Intercellular movement of members of genus Potyvirus, the largest group of RNA viruses, requires diverse host components and at least three viral proteins: CI, P3N-PIPO, and CP. Moreover, P3N-PIPO is the MP that targets CI to PD and forms a conical structure through which the virion or viral RNA/CP complex enters the adjacent cell (Wang 2021). Some viruses extensively modify the PD. For instance, MP in the cowpea mosaic virus forms growing tubules and replaces the appressed ER, leaving a PM-lined tunnel through which the virus can travel (van Lent et al. 1991).

Colocalization and interaction studies have demonstrated that the MP from the grapevine fanleaf virus (another tubule-forming virus) colocalizes and interacts with PDLPs. Furthermore, viral tubule and cell-to-cell spread were compromised in the PDLP triple mutant $p d l p 1 / p d l p 2 / p d l p 3$. Viroids (small, single-stranded, circular RNAs) can also move through the PD and phloem and infect plants (Adkar-Purushothama and Perreault 2020). Some viruses (e.g., potato leafroll virus) are limited to the phloem. They may move as a virion with the $\mathrm{CP}$, independent of the MP (Taliansky et al. 2003).

\section{Filamentous pathogens (oomycetes and fungi).}

Typically, biotrophs germinate on the host surface and attach through appressorium, followed by the apoplastic growth of hyphae, finally forming haustoria (the feeding structure) to obtain nutrients from the host. In contrast, necrotrophs derive nutrients by killing the host tissue and spreading from one cell to another. Hemibiotrophic fungi such as Magnaporthe oryzae breach the cuticle to form appressoria (infected cells) and rapidly colonize the host by forming invasive hyphae and secreting effectors, which can migrate from cell to cell and suppress host immunity (Giraldo et al. 2013). However, the signal or factor that drives the translocation is still debatable.

These pathogens use the PD as a suitable entry point to grow and invade the neighboring cells. In addition, invasive hyphae might constrict to pass through the PD (Kankanala et al. 2007). Inhibition of a single fungal MAPK, Pmk1, prevents the fungus from infecting neighboring cells (Sakulkoo et al. 2018). Due to their rapid colonization, the disease lesions appear within 4 to 5 days. Some oomycetes such as Hyaloperonospora arabidopsidis exploit stomata to reproduce through the emergence and spread of conidiosphore (Coates and Beynon 2010).

\section{Bacteria.}

Bacteria can enter plant tissues through natural openings or wounds and colonize the apoplast. However, unlike viruses and fungi, bacteria do not directly enter and spread through the

Table 1. Summary of phytohormone roles in defense and intercellular communication

\begin{tabular}{|c|c|c|c|c|c|}
\hline Hormone & Affect $^{a}$ & Transport mode & Defense role ${ }^{b}$ & Role against pathogen & References \\
\hline Salicylic acid & Yes & Apoplast & ETI, SAR & Biotrophs, necrotrophs & $\begin{array}{l}\text { Al-Daoude et al. 2019; Lim et al. 2016; Mittag and } \\
\text { Strader 2020; Wang et al. 2013; Wildermuth et al. } \\
2001\end{array}$ \\
\hline Jasmonates & Yes & Symplast, apoplast & ETS & $\begin{array}{l}\text { Necrotrophs, biotrophs, } \\
\text { nematodes }\end{array}$ & $\begin{array}{l}\text { Antico et al. 2012; Farmer et al. 2014; Li et al. 2017; } \\
\text { Lim et al. 2016; Nakano and Mukaihara 2019; } \\
\text { Yimer et al. } 2018\end{array}$ \\
\hline Auxin & Yes & Symplast, apoplast & PTI, ETI & Biotrophs, necrotrophs & $\begin{array}{l}\text { Han et al. 2014; Kazan and Manners 2009; Qi et al. } \\
\text { 2012; Robert and Friml } 2009\end{array}$ \\
\hline Abscisic acid & Yes & Symplast, apoplast & ETI & Necrotrophs & $\begin{array}{l}\text { Benitez-Alfonso 2019; Mine et al. 2017; Tylewicz } \\
\text { et al. } 2018\end{array}$ \\
\hline Ethylene & - & Free diffusion, apoplast & ETI & Biotrophs, necrotrophs & Guan et al. 2015; Yang et al. 2017 \\
\hline Gibberellins & Yes & Symplast & - & Bacteria, necrotrophs & Kwiatkowska 1991; Navarro et al. 2008 \\
\hline Cytokinins & Yes & Symplast & PTI, ETI & Biotrophs, necrotrophs & Bishopp et al. 2011; Naseem et al. 2015 \\
\hline
\end{tabular}




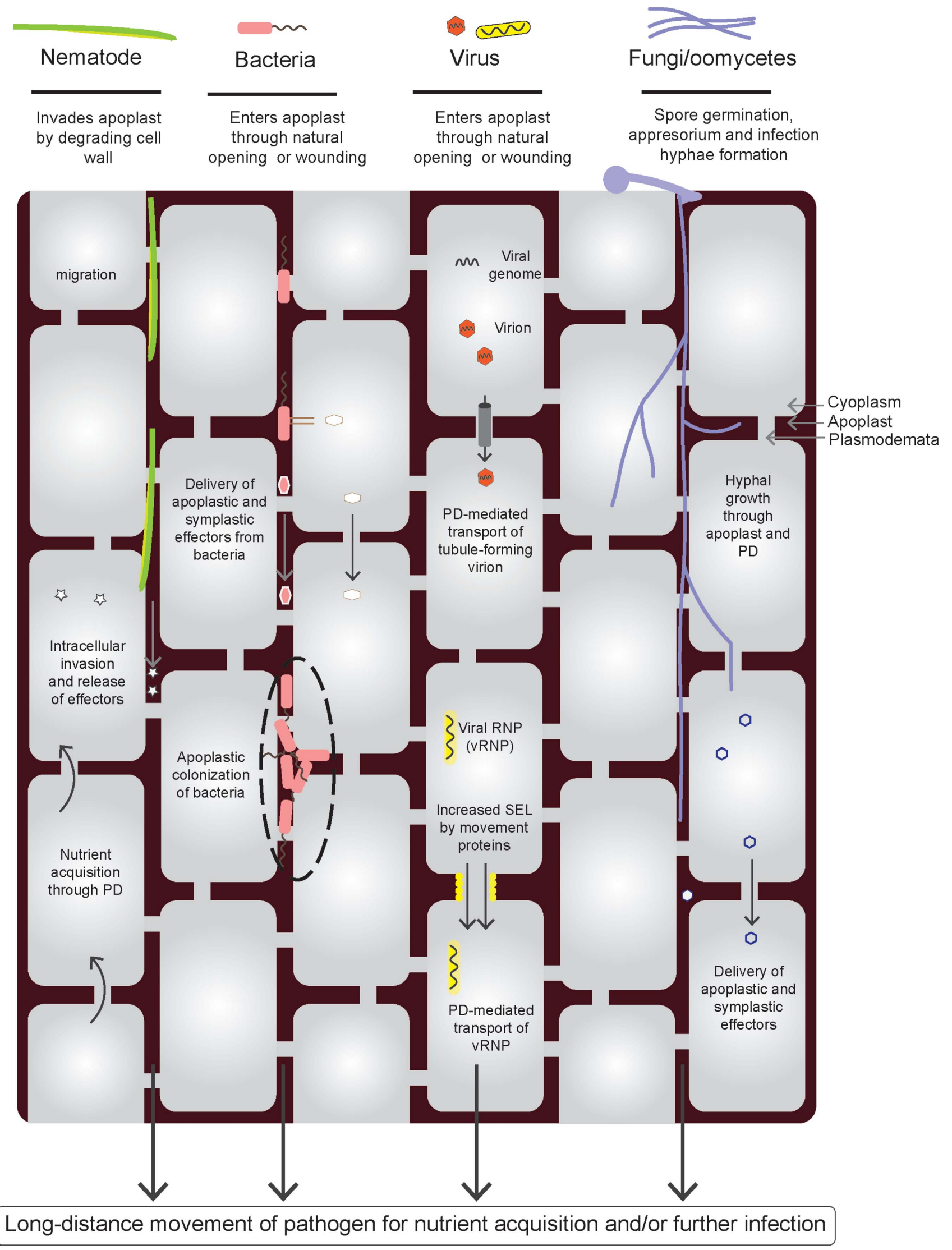

Fig. 2. Phytopathogenic invasion and infection such as nematodes, bacteria, viruses, and fungi. Nematodes migrate through the apoplast and invade the cell at the feeding site for nutrient acquisition. Nematodes also hijack cellular signaling pathways and generate plasmodesmatal (PD) biogenesis. Bacteria and viruses enter the apoplast through openings. Bacteria may colonize the apoplast and deliver mobile effectors, whereas the virion can move with the movement protein by manipulating and exploiting the PD. Unlike these, necrotrophic or biotrophic spores of filamentous pathogens germinate in the host surface, and infection hyphae grow through the intercellular spaces. Most phytopathogens directly or indirectly exploit cell-to-cell connections (the $\mathrm{PD}$, apoplasts, and phloem) for movement, nutrients, or infection. 
intracellular space, instead delivering effectors using the secretion system. The effectors can diffuse through the interphase between the host cell and bacteria (apoplastic effectors) or translocate through the host cell through the PD (symplastic effectors). In both cases, diffusing and translocating effectors can act on several cells.

The predicted translocating signals are type III secretions in bacteria. However, in several cases, the translocation is a pathogen-derived trigger. After translocation, effectors can then localize to different intracellular compartments such as nucleocytoplasm (HopU1), chloroplasts (HopN1), mitochondria (HopG1), and the trans-Golgi network or early endosome (HopM1) (Fu et al. 2007; Nomura et al. 2011). Effectors could manipulate the PD function for further susceptibility of plants. For example, HopO1-1, the effector from P. syringae DC3000, interacts with PDLP5 and PDLP7 (Aung et al. 2020). Given that PDLP5 is crucial for bacterial immunity, HopO1-1 degrades PDLP7, presumably after ribosylation. Moreover, HopO1-1 alters PD trafficking contributing to bacterial virulence.

\section{CELL-TO-CELL MOVEMENT OF IMMUNITY-RELATED PROTEINS AND RNAS}

Several proteins involved in growth and development move symplastically from cell to cell (Gundu et al. 2020). However, the intercellular movement of proteins due to biotic or abiotic stress is not yet clearly illustrated. Signaling molecules such as ROS participate in various processes, including development and defense.

A novel transcription factor, UPBEAT1 (UPB1), modulates ROS by directly regulating peroxidase genes and is also believed to move from cell to cell to specify the position of cellular differentiation (Tsukagoshi et al. 2010). In addition, UPB1 modulates the expression of peroxidases and balances ROS between zone proliferation and the elongation zone in the roots. The stabilization and transcriptional activity of UPB1 are enhanced upon phosphorylation by the BIN2 kinase, a negative regulator of brassinosteroid signaling ( $\mathrm{Li}$ et al. 2020). Although brassinosteroids and PTI signaling are antagonistically coupled (Belkhadir et al. 2012), the direct involvement of a mobile protein such as UBP1 in the PAMP response has not yet been demonstrated.

Another membrane-associated protein, thioredoxin h9 (TRX h9), acts as an antioxidant through the response to the ROS species and undergoes intercellular movement (Meng et al. 2010). However, TRX h9 has no transmembrane domain. It associates with the membrane through palmitoylation of the Gly and Cys residue in the $\mathrm{N}$-terminal domain. Mutation in these residues also restricts the cell-to-cell movement, indicating that this posttranslational modification not only regulates solubility but also is critical for the cell-to-cell movement of TRX h9. Although it has not yet been demonstrated that redox-based signaling is affected by the movement of TRX h9 or UPB1, it is tempting to suggest that regulating the cell-to-cell movement of antioxidants could play a role in preventing oxidative stress in the development and stress responses.

Noncell-autonomous functions in plants are also executed by the cell-to-cell or long-distance movement of mRNAs. However, long-distance trafficking of mRNA through the phloem relies on multiple translocation steps from the source to sink through the phloem (Kehr and Buhtz 2008). The detection of mobile mRNA has been demonstrated through grafting, although it has been challenging to identify the population of RNA involved in stress signaling against a background of general systemic signaling.

Mobile mRNA is believed to play a critical role in growth and defense or stress regulation (Ham and Lucas 2017). In pumpkin (Cucurbita maxima), CmWRKYP transcripts, which have a role in the defense response, were detected in the phloem (Ruiz-Medrano et al. 1999). In 2016, Zhang and colleagues found that many mRNAs are translocated through the phloem under phosphate stress (Zhang et al. 2016). The expression and translocation of phloem-mobile mRNA and micro-RNA (miRNA) occur in a tissue-specific manner. For instance, the miRNA miR399, which plays a role in phosphate homeostasis, is predominantly expressed in vasculature. Under phosphate deficiency, its expression increases and it accumulates in roots, where it targets $\mathrm{PHO}_{2}$, a negative regulator of phosphate transport (Ham and Lucas 2017).

Although the specific subset of miRNA and all small-interfering RNAs are present in phloem extracts due to their smaller sizes, their role in plant defense is well known (Kehr and Buhtz 2008; Liu et al. 2017; Muhammad et al. 2019). For instance, the tomato miR482 and 2118 miRNAs target numerous NBS-LRR mRNAs that encode plants' innate immunity receptors (Shivaprasad et al. 2012). This regulation is lost in virus- and bacteria-infected plants, indicating that miRNAs can be a crucial regulator in some plant diseases. Epitranscriptomic modifications such as the methylation of cytosine $\left(\mathrm{m}^{5} \mathrm{C}\right)$ and N6-methyladenosine $\left(\mathrm{m}^{6} \mathrm{~A}\right)$ regulate gene expression at the posttranscriptional level and the mobility of RNA during stress ( $\mathrm{Hu}$ et al. 2019; Yang et al. 2019). Overall, these suggest that plants may tightly regulate their defense responses through mobile RNAs.

\section{CONCLUSION AND PERSPECTIVE}

Intercellular communication is an essential and highly regulated process, especially during plant defense. This includes the apoplastic and symplastic movement of micromolecules (ROS, hormones, and peptides) and macromolecules (mobile transcription factors). These mobile signals may interact synergistically or antagonistically during PTI, ETI, and SAR and differentially regulate the apoplastic composition or PD permeability. However, how the exact regulatory mechanism works at the transcriptional, epitranscriptional, posttranscriptional, and posttranslational levels is still unclear.

Furthermore, how the overall information is integrated at the PD or apoplast and executed at local and systemic levels remains unanswered. A time-efficient realistic approach to exploring a particular plant-pathogen interaction is to use the machine-learning technique for multiomics data integration obtained from organs, tissues, and single cells. Network biology, deep learning, and other machine-learning approaches can be applied to predict the strategy through which a pathogen exploits cell-to-cell communication for pathogenesis. Real-time monitoring and advanced imaging of intercellularly transported signaling molecules would help explain how plants (and plant organs) respond, tolerate, and adapt to a given biotic or abiotic stress. In the long run, these would improve crop resistance, yield, and nutritional quality in efficient and sustainable agriculture, which is the ultimate aspiration of this research.

\section{LITERATURE CITED}

Adkar-Purushothama, C. R., and Perreault, J.-P. 2020. Current overview on viroid-host interactions. Wiley Interdiscip. Rev. RNA 11:e1570.

Ahuja, I., Kissen, R., and Bones, A. M. 2012. Phytoalexins in defense against pathogens. Trends Plant Sci. 17:73-90.

Al-Daoude, A., Al-Shehadah, E., Shoaib, A., Jawhar, M., and Arabi, M. I. E. 2019. Salicylic acid pathway changes in barley plants challenged with either a biotrophic or a necrotrophic pathogen. Cereal Res. Commun. 47:324-333.

Alazem, M., and Lin, N. S. 2017. Antiviral roles of abscisic acid in plants. Front. Plant Sci. 8:1760.

Albers, P., Üstün, S., Witzel, K., Kraner, M., and Börnke, F. 2019. A remorin from Nicotiana benthamiana interacts with the Pseudomonas 
type-III effector protein HopZ1a and is phosphorylated by the immune-related kinase PBS1. Mol. Plant-Microbe Interact. 32:1229. 1242.

Antico, C. J., Colon, C., Banks, T., and Ramonell, K. M. 2012. Insights into the role of jasmonic acid-mediated defenses against necrotrophic and biotrophic fungal pathogens. Front. Biol. 7:48-56.

Aung, K., Jiang, Y., and He, S. Y. 2018. The role of water in plant-microbe interactions. Plant J. 93:771-780.

Aung, K., Kim, P., Li, Z., Joe, A., Kvitko, B., Alfano, J. R., and He, S. Y. 2020. Pathogenic bacteria target plant plasmodesmata to colonize and invade surrounding tissues. Plant Cell 32:595-611.

Band, L. R. 2021. Auxin fluxes through plasmodesmata. New Phytol. 231:1686-1692.

Belkhadir, Y., Jaillais, Y., Epple, P., Balsemão-Pires, E., Dangl, J. L., and Chory, J. 2012. Brassinosteroids modulate the efficiency of plant immune responses to microbe-associated molecular patterns. Proc. Natl. Acad. Sci. U.S.A. 109:297-302.

Bell, K., and Oparka, K. 2011. Imaging plasmodesmata. Protoplasma 248:9-25.

Bellafiore, S., Shen, Z., Rosso, M. N., Abad, P., Shih, P., and Briggs, S. P. 2008. Direct identification of the Meloidogyne incognita secretome reveals proteins with host cell reprogramming potential. PLoS Pathog. 4:e1000192.

Benitez-Alfonso, Y. 2019. The role of abscisic acid in the regulation of plasmodesmata and symplastic intercellular transport. Plant Cell Physiol. 60:713-714

Benitez-Alfonso, Y., Cilia, M., San Roman, A., Thomas, C., Maule, A., Hearn, S., and Jackson, D. 2009. Control of Arabidopsis meristem development by thioredoxin-dependent regulation of intercellular transport. Proc. Natl. Acad. Sci. U.S.A. 106:3615-3620.

Bishopp, A., Lehesranta, S., Vatén, A., Help, H., El-Showk, S., Scheres, B., Helariutta, K., Mähönen, A. P., Sakakibara, H., and Helariutta, Y. 2011. Phloem-transported cytokinin regulates polar auxin transport and maintains vascular pattern in the root meristem. Curr. Biol. 21: 927-932.

Bourdais, G., Burdiak, P., Gauthier, A., Nitsch, L., Salojärvi, J., Rayapuram, C., Idänheimo, N., Hunter, K., Kimura, S., Merilo, E., Vaattovaara, A., Oracz, K., Kaufholdt, D., Pallon, A., Anggoro, D. T., Glów, D., Lowe, J., Zhou, J., Mohammadi, O., Puukko, T., Albert, A., Lang, H., Ernst, D., Kollist, H., Brosché, M., Durner, J., Borst, J. W., Collinge, D. B., Karpiński, S., Lyngkjær, M. F., Robatzek, S., Wrzaczek, M., and Kangasjärvi, J. 2015. Large-scale phenomics identifies primary and fine-tuning roles for CRKs in responses related to oxidative stress. PLoS Genet. 11:e1005373.

Caillaud, M. C., Wirthmueller, L., Sklenar, J., Findlay, K., Piquerez, S. J. M., Jones, A. M. E., Robatzek, S., Jones, J. D. G., and Faulkner, C. 2014. The plasmodesmal protein PDLP1 localises to haustoriaassociated membranes during downy mildew infection and regulates callose deposition. PLoS Pathog. 10:e1004496.

Cao, L., Blekemolen, M. C., Tintor, N., Cornelissen, B. J. C., and Takken, F. L. W. 2018. The Fusarium oxysporum Avr2-Six5 effector pair alters plasmodesmatal exclusion selectivity to facilitate cell-to-cell movement of Avr2. Mol. Plant. 11:691-705.

Carella, P., Isaacs, M., and Cameron, R. K. 2015. Plasmodesmata-located protein overexpression negatively impacts the manifestation of systemic acquired resistance and the long-distance movement of defective in induced resistance1 in Arabidopsis. Plant Biol. 17:395-401.

Cheval, C., and Faulkner, C. 2018. Plasmodesmal regulation during plantpathogen interactions. New Phytol. 217:62-67.

Coates, M. E., and Beynon, J. L. 2010. Hyaloperonospora arabidopsidis as a pathogen model. Annu. Rev. Phytopathol. 48:329-345.

Cui, W., and Lee, J. Y. 2016. Arabidopsis callose synthases CalS1/8 regulate plasmodesmal permeability during stress. Nat. Plants 2:16034.

Daum, G., Medzihradszky, A., Suzaki, T., and Lohmann, J. U. 2014. A mechanistic framework for noncell autonomous stem cell induction in Arabidopsis. Proc. Natl. Acad. Sci. U.S.A. 111:14619-14624.

De Bruyne, L., Höfte, M., and De Vleesschauwer, D. 2014. Connecting growth and defense: The emerging roles of brassinosteroids and gibberellins in plant innate immunity. Mol. Plant 7:943-959.

Djamei, A., Schipper, K., Rabe, F., Ghosh, A., Vincon, V., Kahnt, J., Osorio, S., Tohge, T., Fernie, A. R., Feussner, I., Feussner, K., Meinicke, P., Stierhof, Y. D., Schwarz, H., MacEk, B., Mann, M., and Kahmann, R. 2011. Metabolic priming by a secreted fungal effector. Nature 478:395-398.

Farmer, E. E., Gasperini, D., and Acosta, I. F. 2014. The squeeze cell hypothesis for the activation of jasmonate synthesis in response to wounding. J. Physiol. 204:282-288.
Faulkner, C., Petutschnig, E., Benitez-Alfonso, Y., Beck, M., Robatzek, S., Lipka, V., and Maule, A. J. 2013. LYM2-dependent chitin perception limits molecular flux via plasmodesmata. Proc. Natl. Acad. Sci. U.S.A. 110:9166-9170

Fernandez-Calvino, L., Faulkner, C., Walshaw, J., Saalbach, G., Bayer, E., Benitez-Alfonso, Y., and Maule, A. 2011. Arabidopsis plasmodesmal proteome. PLoS One 6:e18880.

Fu, Z. Q., and Dong, X. 2013. Systemic acquired resistance: Turning local infection into global defense. Annu. Rev. Plant Biol. 64:839-863.

Fu, Z. Q., Guo, M., Jeong, B. R., Tian, F., Elthon, T. E., Cerny, R. L., Staiger, D., and Alfano, J. R. 2007. A type III effector ADPribosylates RNA-binding proteins and quells plant immunity. Nature 447:284-288.

Gao, C., Liu, X., De Storme, N., Jensen, K. H., Xu, Q., Yang, J., Liu, X., Chen, S., Martens, H. J., Schulz, A., and Liesche, J. 2020. Directionality of plasmodesmata-mediated transport in Arabidopsis leaves supports auxin channeling. Curr. Biol. 30:1970-1977.e4.

García-Andrade, J., González, B., Gonzalez-Guzman, M., Rodriguez, P. L., and Vera, P. 2020. The role of ABA in plant immunity is mediated through the PYR1 receptor. Int. J. Mol. Sci. 21:5852.

Geldner, N. 2013. The endodermis. Annu. Rev. Plant Biol. 64:531-558.

Giraldo, M. C., Dagdas, Y. F., Gupta, Y. K., Mentlak, T. A., Yi, M., MartinezRocha, A. L., Saitoh, H., Terauchi, R., Talbot, N. J., and Valent, B. 2013. Two distinct secretion systems facilitate tissue invasion by the rice blast fungus Magnaporthe oryzae. Nat. Commun. 4:1996.

Grison, M. S., Brocard, L., Fouillen, L., Nicolas, W., Wewer, V., Dörmann, P., Nacir, H., Benitez-Alfonso, Y., Claverol, S., Germain, V., Boutté, Y., Mongrand, S., and Bayer, E. M. 2015. Specific membrane lipid composition is important for plasmodesmata function in Arabidopsis. Plant Cell 27:1228-1250.

Guan, R., Su, J., Meng, X., Li, S., Liu, Y., Xu, J., and Zhang, S. 2015. Multilayered regulation of ethylene induction plays a positive role in Arabidopsis resistance against Pseudomonas syringae. Plant Physiol. 169:299-312.

Gundu, S., Tabassum, N., and Blilou, I. 2020. Moving with purpose and direction: Transcription factor movement and cell fate determination revisited. Curr. Opin. Plant Biol. 57:124-132.

Gupta, R., Pizarro, L., Leibman-Markus, M., Marash, I., and Bar, M. 2020. Cytokinin response induces immunity and fungal pathogen resistance, and modulates trafficking of the PRR LeEIX2 in tomato. Mol Plant Pathol. 21:1287-1306.

Ham, B. K., and Lucas, W. J. 2017. Phloem-mobile RNAs as systemic signaling agents. Annu. Rev. Plant Biol. 68:173-195.

Han, X., Hyun, T. K., Zhang, M., Kumar, R., Koh, E.-j., Kang, B.-H., Lucas, W. J., and Kim, J.-Y. 2014. Auxin-callose-mediated plasmodesmal gating is essential for tropic auxin gradient formation and signaling. Dev. Cell 28:132-146.

Helariutta, Y., Fukaki, H., Wysocka-Diller, J., Nakajima, K., Jung, J., Sena, G., Hauser, M. T., and Benfey, P. N. 2000. The SHORT-ROOT gene controls radial patterning of the Arabidopsis root through radial signaling. Cell 101:555-567.

Hewezi, T., and Baum, T. J. 2017. Communication of sedentary plantparasitic nematodes with their host plants. Adv. Bot. Res. 82:305-324.

Hofmann, J., and Grundler, F. M. W. 2006. Females and males of rootparasitic cyst nematodes induce different symplasmic connections between their syncytial feeding cells and the phloem in Arabidopsis thaliana. Plant Physiol. Biochem. 44:430-433.

Hoth, S., Stadler, R., Sauer, N., and Hammes, U. Z. 2008. Differential vascularization of nematode-induced feeding sites. Proc. Natl. Acad. Sci. U.S.A. 105:12617-12622.

Hu, J., Manduzio, S., and Kang, H. 2019. Epitranscriptomic RNA methylation in plant development and abiotic stress responses. Front. Plant Sci. 10:500.

Huang, D., Sun, Y., Ma, Z., Ke, M., Cui, Y., Chen, Z., Chen, C., Ji, C., Tran, T. M., Yang, L., Lam, S. M., Han, Y., Shu, G., Friml, J., Miao, Y., Jiang, L., and Chen, X. 2019. Salicylic acid-mediated plasmodesmal closure via Remorin-dependent lipid organization. Proc. Natl Acad. Sci. U.S.A. 116:21274-21284.

Jones, M. G. K. 1981. The development and function of plant cells modified by endoparasitic nematodes. Pages 255-279 in: Plant Parasitic Nematodes. B. M. Zuckerman and R. A. Rohde, eds. Academic Press, New York, NY, U.S.A.

Jones, J. D. G., and Dangl, J. L. 2006. The plant immune system. Nature 444:323-329.

Kämper, J., Kahmann, R., Bölker, M., Ma, L. J., Brefort, T., Saville, B. J., Banuett, F., Kronstad, J. W., Gold, S. E., Müller, O., Perlin, M. H., Wösten, H. A. B., De Vries, R., Ruiz-Herrera, J., Reynaga- 
Peña, C. G., Snetselaar, K., McCann, M., Pérez-Martín, J., Feldbrügge, M., Basse, C. W., Steinberg, G., Ibeas, J. I., Holloman, W., Guzman, P., Farman, M., Stajich, J. E., Sentandreu, R., González-Prieto, J. M., Kennell, J. C., Molina, L., Schirawski, J., Mendoza-Mendoza, A., Greilinger, D., Münch, K., Rössel, N., Scherer, M., Vraněs, M., Ladendorf, O., Vincon, V., Fuchs, U., Sandrock, B., Meng, S., Ho, E. C. H., Cahill, M. J., Boyce, K. J., Klose, J., Klosterman, S. J., Deelstra, H. J., Ortiz-Castellanos, L., Li, W., Sanchez-Alonso, P., Schreier, P. H., Häuser-Hahn, I., Vaupel, M., Koopmann, E., Friedrich, G., Voss, H., Schlüter, T., Margolis, J., Platt, D., Swimmer, C., Gnirke, A., Chen, F., Vysotskaia, V., Mannhaupt, G., Güldener, U., Münsterkötter, M., Haase, D., Oesterheld, M., Mewes, H. W., Mauceli, E. W., DeCaprio, D., Wade, C. M., Butler, J., Young, S., Jaffe, D. B., Calvo, S., Nusbaum, C., Galagan, J., and Birren, B. W. 2006. Insights from the genome of the biotrophic fungal plant pathogen Ustilago maydis. Nature 444:97-101.

Kankanala, P., Czymmek, K., and Valent, B. 2007. Roles for rice membrane dynamics and plasmodesmata during biotrophic invasion by the blast fungus. Plant Cell 19:706-724.

Kaplan, I. B., Zhang, L., and Palukaitis, P. 1998. Characterization of cucumber mosaic virus: V. Cell-to-cell movement requires capsid protein but not virions. Virology 246:221-231.

Kazan, K., and Manners, J. M. 2009. Linking development to defense: Auxin in plant-pathogen interactions. Trends Plant Sci. 14:373-382.

Kehr, J., and Buhtz, A. 2008. Long distance transport and movement of RNA through the phloem. J. Exp. Bot. 59:85-92.

Khang, C. H., Berruyer, R., Giraldo, M. C., Kankanala, P., Park, S. Y., Czymmek, K., Kang, S., and Valent, B. 2010. Translocation of Magnaporthe oryzae effectors into rice cells and their subsequent cellto-cell movement. Plant Cell 22:1388-1403.

Kitagawa, M., Tomoi, T., Fukushima, T., Sakata, Y., Sato, M., Toyooka, K. Fujita, T., and Sakakibara, H. 2019. Abscisic acid acts as a regulator of molecular trafficking through plasmodesmata in the moss Physcomitrella patens. Plant Cell Physiol. 60:738-751.

Kunze, G., Zipfel, C., Robatzek, S., Niehaus, K., Boller, T., and Felix, G. 2004. The $\mathrm{N}$ terminus of bacterial elongation factor $\mathrm{Tu}$ elicits innate immunity in Arabidopsis plants. Plant Cell 16:3496-3507.

Kwiatkowska, M. 1991. Autoradiographic studies on the role of plasmodesmata in the transport of gibberellin. Planta 183:294-299.

Lee, J. Y., and Frank, M. 2018. Plasmodesmata in phloem: Different gateways for different cargoes. Curr. Opin. Plant Biol. 43:119-124.

Lee, J.-Y., and Lu, H. 2011. Plasmodesmata: The battleground against intruders. Trends Plant Sci. 16:201-210.

Lee, J. Y., Wang, X., Cui, W., Sager, R., Modla, S., Czymmek, K., Zybaliov, B., Van Wijk, K., Zhang, C., Lu, H., and Lakshmanana, V. 2011. A plasmodesmata-localized protein mediates crosstalk between cell-to-cell communication and innate immunity in Arabidopsis. Plant Cell 23:3353-3373.

Lee, M. W., Jelenska, J., and Greenberg, J. T. 2008. Arabidopsis proteins important for modulating defense responses to Pseudomonas syringae that secrete HopW1-1. Plant J. 54:452-465.

Lewis, J. D., Guttman, D. S., and Desveaux, D. 2009. The targeting of plant cellular systems by injected type III effector proteins. Semin. Cell Dev. Biol. 20:1055-1063.

Li, Q., Zheng, J., Li, S., Huang, G., Skilling, S. J., Wang, L., Li, L., Li, M., Yuan, L., and Liu, P. 2017. Transporter-mediated nuclear entry of jasmonoyl-isoleucine is essential for jasmonate signaling. Mol. Plant 10:695-708.

Li, T., Lei, W., He, R., Tang, X., Han, J., Zou, L., Yin, Y., Lin, H., and Zhang, D. 2020. Brassinosteroids regulate root meristem development by mediating BIN2-UPB1 module in Arabidopsis. PLoS Genet. 16: e1008883.

Li, Z., Variz, H., Chen, Y., Liu, S.-L., and Aung, K. 2021. Plasmodesmata-dependent intercellular movement of bacterial effectors. Front. Plant Sci. 12:464

Lim, G. H., Liu, H., Yu, K., Liu, R., Shine, M. B., Fernandez, J., BurchSmith, T., Mobley, J. K., McLetchie, N., Kachroo, A., and Kachroo, P. 2020. The plant cuticle regulates apoplastic transport of salicylic acid during systemic acquired resistance. Sci. Adv. 6:eaaz0478.

Lim, G. H., Shine, M. B., De Lorenzo, L., Yu, K., Cui, W., Navarre, D., Hunt, A. G., Lee, J. Y., Kachroo, A., and Kachroo, P. 2016. Plasmodesmata localizing proteins regulate transport and signaling during systemic acquired immunity in plants. Cell Host Microbe 19: 541-549.

Liu, S. R., Zhou, J. J., Hu, C. G., Wei, C. L., and Zhang, J. Z. 2017. MicroRNA-mediated gene silencing in plant defense and viral counter-defense. Front. Microbiol. 8:1801.
Lucas, W. J., and Lee, J. Y. 2004. Plasmodesmata as a supracellular control network in plants. Nat. Rev. Mol. Cell Biol. 5:712-726.

Mao, G., Meng, X., Liu, Y., Zheng, Z., Chen, Z., and Zhang, S. 2011. Phosphorylation of a WRKY transcription factor by two pathogenresponsive MAPKs drives phytoalexin biosynthesis in Arabidopsis. Plant Cell 23:1639-1653.

Meng, L., Wong, J. H., Feldman, L. J., Lemaux, P. G., and Buchanan, B. B. 2010. A membrane-associated thioredoxin required for plant growth moves from cell to cell, suggestive of a role in intercellular communication. Proc. Natl. Acad. Sci. U.S.A. 107:3900-3905.

Miedes, E., Vanholme, R., Boerjan, W., and Molina, A. 2014. The role of the secondary cell wall in plant resistance to pathogens. Front. Plant Sci. 5:358.

Mielke, K., Forner, S., Kramell, R., Conrad, U., and Hause, B. 2011. Cell-specific visualization of jasmonates in wounded tomato and Arabidopsis leaves using jasmonate-specific antibodies. New Phytol. 190: 1069-1080.

Mine, A., Berens, M. L., Nobori, T., Anver, S., Fukumoto, K., Winkelmüller, T. M., Takeda, A., Becker, D., and Tsuda, K. 2017. Pathogen exploitation of an abscisic acid- and jasmonate-inducible MAPK phosphatase and its interception by Arabidopsis immunity. Proc. Natl. Acad. Sci. U.S.A. 114:7456-7461.

Mittag, T., and Strader, L. C. 2020. I will survive: How NPR1 condensation promotes plant cell survival. Cell 182:1072-1074.

Morozov, S. Y., and Solovyev, A. G. 2003. Triple gene block: Modular design of a multifunctional machine for plant virus movement. J. Gen. Virol. 84:1351-1366.

Muhammad, T., Zhang, F., Zhang, Y., and Liang, Y. 2019. RNA interference: A natural immune system of plants to counteract biotic stressors Cells 8:38.

Murillo, I., Cavallarin, L., and San Segundo, B. 1997. The maize pathogenesis-related PRms protein localizes to plasmodesmata in maize radicles. Plant Cell 9:145-156.

Nakajima, K., Sena, G., Nawy, T., and Benfey, P. N. 2001. Intercellular movement of the putative transcription factor SHR in root patterning. Nature 413:307-311.

Nakano, M., and Mukaihara, T. 2019. Comprehensive identification of PTI suppressors in type III effector repertoire reveals that Ralstonia solanacearum activates jasmonate signaling at two different steps. Int. J. Mol. Sci. 20:5992

Naseem, M., Kaltdorf, M., and Dandekar, T. 2015. The nexus between growth and defence signalling: Auxin and cytokinin modulate plant immune response pathways. J. Exp. Bot. 66:4885-4896.

Navarro, L., Bari, R., Achard, P., Lisón, P., Nemri, A., Harberd, N. P., and Jones, J. D. G. 2008. DELLAs control plant immune responses by modulating the balance of jasmonic acid and salicylic acid signaling. Curr. Biol. 18:650-655.

Ngou, B. P. M., Ahn, H. K., Ding, P., and Jones, J. D. G. 2020. Mutual potentiation of plant immunity by cell-surface and intracellular receptors. bioRxiv 10.034173

Nomura, K., Mecey, C., Lee, Y. N., Imboden, L. A., Chang, J. H., and He, S. Y. 2011. Effector-triggered immunity blocks pathogen degradation of an immunity-associated vesicle traffic regulator in Arabidopsis. Proc. Natl. Acad. Sci. U.S.A. 108:10774-10779.

O'Brien, J. A., Daudi, A., Butt, V. S., and Bolwell, G. P. 2012. Reactive oxygen species and their role in plant defence and cell wall metabolism. Planta 236:765-779.

Ormenese, S., Bernier, G., and Périlleux, C. 2006. Cytokinin application to the shoot apical meristem of Sinapis alba enhances secondary plasmodesmata formation. Planta 224:1481-1484.

Osbourn, A. E. 1996. Preformed antimicrobial compounds and plant defense against fungal attack. Plant Cell 8:1821-1831.

Pike, S. M., Zhang, X. C., and Gassmann, W. 2005. Electrophysiological characterization of the Arabidopsis avrRpt2-specific hypersensitive response in the absence of other bacterial signals. Plant Physiol. 138:1009-1017.

Qi, J., Wang, J., Gong, Z., and Zhou, J. M. 2017. Apoplastic ROS signaling in plant immunity. Curr. Opin. Plant Biol. 38:92-100.

Qi, L., Yan, J., Li, Y., Jiang, H., Sun, J., Chen, Q., Li, H., Chu, J., Yan, C., Sun, X., Yu, Y., Li, C., and Li, C. 2012. Arabidopsis thaliana plants differentially modulate auxin biosynthesis and transport during defense responses to the necrotrophic pathogen Alternaria brassicicola. New Phytol. 195:872-882.

Ranathunge, K., Steudle, E., and Lafitte, R. 2005. Blockage of apoplastic bypass-flow of water in rice roots by insoluble salt precipitates analogous to a Pfeffer cell. Plant Cell Environ. 28:121-133.

Rinne, P. L. H., Kaikuranta, P. M., and Der Van Schoot, C. 2001. The shoot apical meristem restores its symplasmic organization during chilling-induced release from dormancy. Plant J. 26:249-264. 
Rinne, P. L. H., and van der Schoot, C. 2003. Plasmodesmata at the crossroads between development, dormancy, and defense. Can. J. Bot. 81:1182-1197.

Robert, H. S., and Friml, J. 2009. Auxin and other signals on the move in plants. Nat. Chem. Biol. 5:325-332.

Ruiz-Medrano, R., Xoconostle-Cázares, B., and Lucas, W. J. 1999. Phloem long-distance transport of CmNACP mRNA: Implications for supracellular regulation in plants. Development 126:4405-4419.

Saatian, B., Austin, R. S., Tian, G., Chen, C., Nguyen, V., Kohalmi, S. E., Geelen, D., and Cui, Y. 2018. Analysis of a novel mutant allele of GSL8 reveals its key roles in cytokinesis and symplastic trafficking in Arabidopsis. BMC Plant Biol. 18:295.

Sager, R., Wang, X., Hill, K., Yoo, B. C., Caplan, J., Nedo, A., Tran, T., Bennett, M. J., and Lee, J. Y. 2020. Auxin-dependent control of a plasmodesmal regulator creates a negative feedback loop modulating lateral root emergence. Nat. Commun. 11:364.

Sakulkoo, W., Osés-Ruiz, M., Garcia, E. O., Soanes, D. M., Littlejohn, G. R., Hacker, C., Correia, A., Valent, B., and Talbot, N. J. 2018. A single fungal MAP kinase controls plant cell-to-cell invasion by the rice blast fungus. Science 359:1399-1403.

Schoelz, J. E., Harries, P. A., and Nelson, R. S. 2011. Intracellular transport of plant viruses: Finding the door out of the cell. Mol. Plant 4: 813-831.

Shikanai, Y., Yoshida, R., Hirano, T., Enomoto, Y., Li, B., Asada, M., Yamagami, M., Yamaguchi, K., Shigenobu, S., Tabata, R., Sawa, S., Okada, H., Ohya, Y., Kamiya, T., and Fujiwara, T. 2020. Callose synthesis suppresses cell death induced by low-calcium conditions in leaves1. Plant Physiol. 182:2199-2212.

Shivaprasad, P. V., Chen, H. M., Patel, K., Bond, D. M., Santos, B. A C. M., and Baulcombe, D. C. 2012. A microRNA superfamily regulates nucleotide binding site-leucine-rich repeats and other mRNAs. Plant Cell 24:859-874.

Singh, A., Lim, G. H., and Kachroo, P. 2017. Transport of chemical signals in systemic acquired resistance. J. Integr. Plant Biol. 59:336-344.

Somerville, C., Bauer, S., Brininstool, G., Facette, M., Hamann, T., Milne, J., Osborne, E., Paredez, A., Persson, S., Raab, T., Vorwerk, S., and Youngs, H. 2004. Toward a systems approach to understanding plant cell walls. Science 306:2206-2211.

Stahl, Y., and Faulkner, C. 2016. Receptor complex mediated regulation of symplastic traffic. Trends Plant Sci. 21:450-459.

Stonebloom, S., Brunkard, J. O., Cheung, A. C., Jiang, K., Feldman, L., and Zambryski, P. 2012. Redox states of plastids and mitochondria differentially regulate intercellular transport via plasmodesmata. Plant Physiol. 158:190-199.

Taliansky, M., Mayo, M. A., and Barker, H. 2003. Potato leafroll virus: A classic pathogen shows some new tricks. Mol. Plant Pathol. 4:81-89.

Thomas, C. L., Bayer, E. M., Ritzenthaler, C., Fernandez-Calvino, L., and Maule, A. J. 2008. Specific targeting of a plasmodesmal protein affecting cell-to-cell communication. PLoS Biol. 6:e7.

Thomas, R., Fang, X., Ranathunge, K., Anderson, T. R., Peterson, C. A., and Bernards, M. A. 2007. Soybean root suberin: Anatomical distribution, chemical composition, and relationship to partial resistance to Phytophthora sojae. Plant Physiol. 144:299-311.

Tierens, K. F. M. J., Thomma, B. P. H. J., Brouwer, M., Schmidt, J., Kistner, K., Porzel, A., Mauch-Mani, B., Cammue, B. P. A., and Broekaert, W. F. 2001. Study of the role of antimicrobial glucosinolate-derived isothiocyanates in resistance of Arabidopsis to microbial pathogens. Plant Physiol. 125:1688-1699.

Tomczynska, I., Stumpe, M., Doan, T. G., and Mauch, F. 2020. A Phytophthora effector protein promotes symplastic cell-to-cell trafficking by physical interaction with plasmodesmata-localised callose synthases. New Phytol. 227:1467-1478.

Toruño, T. Y., Stergiopoulos, I., and Coaker, G. 2016. Plant-pathogen effectors: Cellular probes interfering with plant defenses in spatial and temporal manners. Annu. Rev. Phytopathol. 54:419-441.

Tsukagoshi, H., Busch, W., and Benfey, P. N. 2010. Transcriptional regulation of ROS controls transition from proliferation to differentiation in the root. Cell 143:606-616.

Tylewicz, S., Petterle, A., Marttila, S., Miskolczi, P., Azeez, A., Singh, R. K., Immanen, J., Mähler, N., Hvidsten, T. R., Eklund, D. M., Bowman, J. L., Helariutta, Y., and Bhalerao, R. P. 2018. Photoperiodic control of seasonal growth is mediated by ABA acting on cell-cell communication. Science 360:212-215.

van Lent, J., Storms, M., van der Meer, F., Wellink, J., and Goldbach, R. 1991. Tubular structures involved in movement of cowpea mosaic virus are also formed in infected cowpea protoplasts. J. Gen. Virol. $72: 2615-2623$
Voigt, C. A., and Somerville, S. C. 2009. Callose in biotic stress (pathogenesis) biology, biochemistry and molecular biology of callose in plant defence: Callose deposition and turnover in plant-pathogen interactions. Pages 525-562 in: Chemistry, Biochemistry, and Biology of 1-3 Beta Glucans and Related Polysaccharides. A. Bacic, G. Fincher, and B. Stone, eds. Academic Press, New York, NY, U.S.A.

von Mende, N. 1997. Invasion and migration behaviour of sedentary nematodes. Pages 51-64 in: Cellular and Molecular Aspects of PlantNematode Interactions. Developments in Plant Pathology, vol. 10. C Fenoll, F. M. W. Grundler, and S. A. Ohl, eds. Springer, Dordrecht, The Netherlands.

Wang, A. 2021. Cell-to-cell movement of plant viruses via plasmodesmata: A current perspective on potyviruses. Curr. Opin. Virol. 48: 10-16.

Wang, X., Sager, R., Cui, W., Zhang, C., Lu, H., and Lee, J.-Y. 2013. Salicylic acid regulates plasmodesmata closure during innate immune responses in Arabidopsis. Plant Cell 25:2315-2329.

Wang, Y., Schuck, S., Wu, J., Yang, P., Döring, A.-C., Zeier, J., and Tsuda, K. 2018. A MPK3/6-WRKY33-ALD1-pipecolic acid regulatory loop contributes to systemic acquired resistance. Plant Cell 30:2480-2494.

Wang, Y., Wang, Y., and Wang, Y. 2020. Apoplastic proteases: Powerful weapons against pathogen infection in plants. Plant Commun. 1: 100085 .

Washington, E. J., Mukhtar, M. S., Finkel, O. M., Wan, L., Banfield, M. J., Kieber, J. J., and Dangl, J. L. 2016. Pseudomonas syringae type III effector HopAF1 suppresses plant immunity by targeting methionine recycling to block ethylene induction. Proc. Natl. Acad. Sci. U.S.A. 113:E3577-E3586.

Wildermuth, M. C., Dewdney, J., Wu, G., and Ausubel, F. M. 2001. Isochorismate synthase is required to synthesize salicylic acid for plant defence. Nature 414:562-565.

Wu, C.-T., and Bradford, K. J. 2003. Class I chitinase and $\beta$-1,3-glucanase are differentially regulated by wounding, methyl jasmonate, ethylene, and gibberellin in tomato seeds and leaves. Plant Physiol. 133: 263-273.

Wyss, U., and Grundler, F. M. W. 1992. Feeding behavior of sedentary plant parasitic nematodes. Neth. J. Plant Pathol. 98:165-173.

Xu, B., Cheval, C., Laohavisit, A., Hocking, B., Chiasson, D., Olsson, T. S. G., Shirasu, K., Faulkner, C., and Gilliham, M. 2017. A calmodulin-like protein regulates plasmodesmal closure during bacterial immune responses. New Phytol. 215:77-84.

Xu, G., Yuan, M., Ai, C., Liu, L., Zhuang, E., Karapetyan, S., Wang, S., and Dong, X. 2017. UORF-mediated translation allows engineered plant disease resistance without fitness costs. Nature 545:491-494.

Yang, C., Li, W., Cao, J., Meng, F., Yu, Y., Huang, J., Jiang, L., Liu, M., Zhang, Z., Chen, X., Miyamoto, K., Yamane, H., Zhang, J., Chen, S., and Liu, J. 2017. Activation of ethylene signaling pathways enhances disease resistance by regulating ROS and phytoalexin production in rice. Plant J. 89:338-353.

Yang, L., Perrera, V., Saplaoura, E., Apelt, F., Bahin, M., Kramdi, A., Olas, J., Mueller-Roeber, B., Sokolowska, E., Zhang, W., Li, R., Pitzalis, N., Heinlein, M., Zhang, S., Genovesio, A., Colot, V., and Kragler, F. 2019. $\mathrm{m}^{5} \mathrm{C}$ methylation guides systemic transport of messenger RNA over graft junctions in plants. Curr. Biol. 29:2465-2476.e5.

Yeats, T. H., and Rose, J. K. C. 2013. The formation and function of plant cuticles. Plant Physiol. 163:5-20.

Yimer, H. Z., Nahar, K., Kyndt, T., Haeck, A., Van Meulebroek, L., Vanhaecke, L., Demeestere, K., Höfte, M., and Gheysen, G. 2018. Gibberellin antagonizes jasmonate-induced defense against Meloidogyne graminicola in rice. New Phytol. 218:646-660.

Yu, K., Soares, J. M., Mandal, M. K., Wang, C., Chanda, B., Gifford, A. N., Fowler, J. S., Navarre, D., Kachroo, A., and Kachroo, P. 2013 A feedback regulatory loop between G3P and lipid transfer proteins DIR1 and AZI1 mediates azelaic-acid-induced systemic immunity. Cell Rep. 3:1266-1278.

Zavaliev, R., Mohan, R., Chen, T., and Dong, X. 2020. Formation of NPR1 condensates promotes cell survival during the plant immune response. Cell 182:1093-1108.e18.

Zhang, Z., Zheng, Y., Ham, B. K., Chen, J., Yoshida, A., Kochian, L. V., Fei, Z., and Lucas, W. J. 2016. Vascular-mediated signalling involved in early phosphate stress response in plants. Nat. Plants 2:16033.

Zhou, F., Emonet, A., Dénervaud Tendon, V., Marhavy, P., Wu, D. Lahaye, T., and Geldner, N. 2020. Co-incidence of damage and microbial patterns controls localized immune responses in roots. Cell 180: 440-453.e18.

Zhou, J.-M., and Zhang, Y. 2020. Plant immunity: Danger perception and signaling. Cell 181:978-989. 